\title{
Comparative Assessment of a Pyrethroid Insecticide with Some Plant Materials for the Control of Podagrica Spp. on Okra, Abelmoschus esculentus (L.) Moench
}

\section{Emeasor KC* and Okpara UD}

Department of Plant Health Management, College of Crop and Soil Sciences, Micheal Okpara University of Agriculture Umudike, Abia State, Nigeria

*Corresponding Author: Emeasor KC, Department of Plant Health Management, College of Crop and Soil Sciences, Micheal Okpara University of Agriculture Umudike, Abia State, Nigeria.

Received: July 29, 2019; Published: October 31, 2019

DOI: 10.31080/ASAG.2019.03.0706

\begin{abstract}
The efficacy of different leaf extracts of Chromolaena odorata, Carica papaya, and Ageratum conyzoides were evaluated in the control of okra (Abelmoschus esculentus (L.) Moench.) Flea beetles (Podagrica spp.) and to compare the plant extracts with a synthetic insecticide (Deltamethrine). The experiment was laid in the Randomized Complete Block design (RCBD) with five treatments and three replicates. The treatment includes $150 \mathrm{~g}$ leaf extracts of Chromolaena odorata, Carica papaya, and Ageratum conyzoides, distilled water (control), and a synthetic insecticide (Deltamethrine) as a standard check. The efficacy of the treatments was evaluated based on reduction of okra flea beetles population and percentage defoliation of leaf lamina. The results indicated that leaf extract of Carica papaya significantly $(\mathrm{p}<0.05)$ reduced the population of flea beetles by $20.7 \%$ and leaf defoliation by $57.7 \%$, other extracts were better than the control (distilled water). All the plant extracts used were not as effective as the synthetic insecticide (Deltamethrine) in reducing both flea beetles population and defoliation of leaf lamina. Among leaf extracts, leaf extract of Carica papaya was found to be most effective, hence its use by farmers is recommended in the protection of okra against infestation by P. uniforma and P. sjostedii as it is biodegradable and environmental friendly.
\end{abstract}

Keywords: Control Podagrica spp.; Okra; Plant Extracts; Chromolaena odorata; Carica papaya; Ageratum conyzoides; Deltamethrine; Randomized Complete Block design (RCBD)

\section{Introduction}

Okra (Abelmoschus esculentus (L.) Moench.) is an annual, herbaceous, $0.91-1.83 \mathrm{~m}$ tall plant with a hibiscus like flower. It belongs to the family "Malvaceae" and order "Malvales". Okra originated somewhere around Ethiopia and was cultivated by the ancient Egyptians by the $12^{\text {th }}$ century B.C. Its cultivation spread throughout Middle East and North Africa and many parts of the world [1]. It is grown in many parts of the world, especially in tropical and sub-tropical countries [2]. Okra is a short day plant, and needs temperatures above $20^{\circ} \mathrm{c}$ for normal growth and development [1]. Germination percentage and speed of emergence are optimal at 30-35oc (Akande., et al. 2003). Harvesting is usually done early in the morning, after which it enters the market (Moekchantuk and Kumar, 2004).

Okra ranks first before other vegetable crops because of its importance [3]. It is an important vegetable in West Africa, India, Brazil, and the United States [4]. In Nigeria, okra is one of the most important vegetables in terms of consumption and production area [5]. Okra occupies about 1.5 million hectares of the arable land in Nigeria alone [6]. The world production of common okra as fresh fruit vegetable is estimated at 1.7 million $t /$ year (Schippers, 2000). In Nigeria, okra production was estimated at $15.4 \%$ in the year 2009-2010, after India at 67.1\% (Varmudy, 2011).
Okra is reach in vitamins, calcium, potassium, and other mineral matters (Adeboye and Oputa, 1996). It can be fried in butter oil and cooked with necessary ingredients (Yadav., et al. 2001). Okra mucilage is suitable for medicinal and industrial applications. It has been medically found that its application serves as plasma replacement or blood volume expander. Industrially, okra mucilage is usually used to glace certain papers and also useful in confectionery [7].

However, the yield of okra has been reported to be very low in Nigeria, hardly up to $7 \mathrm{t} / \mathrm{ha}$ (Schippers, 2000). Among the problems of okra production in Nigeria are insect pest infestation, disease incidence and poor nutrient level. Despite the varieties, okra is known to be attacked by a wide range of insect pests (Fasunwon and Banjo, 2010). Egwuatu [8], reported that Podagrica uniforma, Jacoby and P. sjostedti, Jacoby (Coleoptera: Chrysomelidae) are the most destructive insect species of okra in Nigeria. The two beetles are important vectors of okra mosaic virus (OMV), a tymovirus. Okra is highly infested by this virus in Nigeria if grown without controlling the flea beetles [9]. From times past, efforts have been made to control insect pests of okra such as the one made by Asawalam., et al. [10]. However, the only popular and effective method of controlling these pests in the tropics is largely obtained by the use of synthetic pesticides (Stoll, 2000). Despite the effectiveness of the pesticides, 
the synthetic pesticides are also associated with the various ecological problems such as environmental hazards, lethal effects on non-target organisms, pest resurgence, pest resistance and mammalian toxicity due to residue persistence [11].

Due to the above mentioned challenges, an alternative to the use of synthetic pesticide are sought for in keeping with the philosophy and principle of organic agriculture which advocates the reduction in the usage of synthetic chemicals and stabilization of crop yields to increase farmer's profit, while ensuring ecological balance (Yanggen., et al. 2004). Therefore, plant based insecticides are currently evaluated to meet a new world order of producing crops without the use of agro-chemicals [12]. In view of the importance of okra, the flea beetles that cause considerable crop losses and environmental hazards that results from the use of pesticides, the present study was planned to investigate the potential of three botanicals (Chromolaena odorata, Carica papaya, and Ageratum conyzoides) against field insect pest of okra (Podagrica spp.).

\section{Materials and Methods}

- Experimental Site: This experiment was conducted in the teaching and research farm of the department of Plant Health Management, Michael Okpara University of Agriculture Umudike. (Latitude 05o 29|N, Longitude 07o 33|E and $122 \mathrm{~m}$ above sea level.).

- Source of Seed and Plant Materials: The planting material, an early maturing cultivar of okra seed (Clemson spineless) was obtained from National Agricultural Seeds Council, NRCRI premises Umudike, Abia State. While the plant materials (Chromolaena odorata, Carica papaya, and Ageratum conyzoides) were collected from Umuariaga.

- Field Layout: The experimental design used was randomized complete block design (RCBD) with five treatments replicated three times. The treatments were extracts of Chromolaena odorata, Carica papaya, and Ageratum conyzoides, Deltamethrine (Decis) and distilled water been the control. The experimental plot size was comprised of 15 plots, each measuring $3 \mathrm{~m} \times 2.5 \mathrm{~m}(7.5 \mathrm{~m} 2)$ with $0.5 \mathrm{~m}$ furrow and separated by $1 \mathrm{~m}$ pathway.

- Land Preparation: The field was manually cleared off its vegetation, ploughed, harrowed, and later spade was used to prepare the seed beds.

- Planting: Poultry manure weighing $7 \mathrm{~kg}$ per plot was applied (pre-planting) to the soil to enhance the soil fertility. Before sowing, okra seeds were tested for viability by soaking them in water for 24 hours, where by the non-viable seeds floated and was discarded. The seeds were directly sown to the field at the spacing of $60 \mathrm{~cm}$ between rows and $30 \mathrm{~cm}$ between plants and 2 seeds per hole maintaining the depth of $2 \mathrm{~cm}$. Planting population per plot is 40 stands and overall population was 55,500 stands/hectare. The missing stands (that is those that did not germinate after four days) were replanted one week after germination has taken place.
- Weeding and Other Cultural Practices: Weeding was done manually by hoeing and was done fortnightly. NPK fertilizer in the ratio 20:10:10 was applied at 3WAP (weeks after planting) at the rate of $10 \mathrm{~g}$ per stand using ring method.

- Preparations of Aqueous Extracts: Cold water was used in the extraction of the plant materials. The plant materials (Chromolaena odorata, Carica papaya, and Ageratum conyzoides) were washed with clean water to remove sand, dust and contaminants, air dried for 7-12 days on a clean concrete platform and then pulverized using wooden pestle and mortar so that the active ingredients can be freely released in water. $150 \mathrm{~g}$ of the powder of each of the plant materials was soaked in 1litre of cold water. The resulting solution was stirred continuously for 10 minutes and left to stand for 24 hours. Filtration of the plant extracts was done shortly before application in the field using muslin cloth. The final volume of each extract filtrate was made up by diluting with 1liter of distilled water (Elwell and Mass, 1995)

- Treatment Application: Extracts from the plant materials at the rate of $1.5 \mathrm{~g}$ a.i $\mathrm{g} / \mathrm{liter}$ and distilled water (control) were applied at the seedling stage. Spraying of the plant extracts was done using hand sprayer early in the morning before sunrise because of the photodegradable nature of the extracts.

- Assessment of Population: Assessment of population of the beetles started three weeks after planting (WAP) and the population were estimated by visual observation and counting on 5 randomly selected plants in each plot. This was carried out by gently observing the selected plants and by carefully turning the leaves for correct assessment of the Podagrica species present on each of the okra plants.

- Data Collection: Data collection was done at 7 days intervals between 7-9am when the insects were relatively inactive and easy to spot. The following data were collected from the study; plant height, percentage defoliation, and insect pest population. Percentage defoliation was calculated using the formula below:

- Percentage defoliation $=\frac{\text { Total number of leaves defoliated }}{\text { Total number of leaves in sample }} X \frac{100}{1}$

- Measurement of Yield and Yield Components: Two plants out of the 5 randomly selected plants were used by assessing the height of the plants. The tallest and the shortest plants were measured from the soil level to the apex of the plant and the average height recorded. At 6 weeks after planting (WAP), fresh pod weight was taken harvest.

- Statistical Analysis: Data collected were subjected to analysis of variance (ANOVA) procedure for RCBD and mean were separated using least significant difference (LSD) at five percentage (5\%) probability levels. 


\section{Results}

Effects of plant extracts and synthetic insecticide on the population of flea beetles (Podagrica spp.)

The result of insect population before and after application of treatment is represented in table 1 . In all the treatment used, (leaf extracts of Chromolaena odorata, Carica papaya, Ageratum conyzoides and Deltamethrine) insect populations were significantly $(\mathrm{P}<0.05)$ lower than in distilled water (control)

It was observed that insect populations decreased in plots treated with leaf extracts of Chromolaena odorata, Carica papaya, and Ageratum conyzoides, but the plot treated with leaf extracts of Carica papaya proved most effective in reduction $(20.7 \%)$ of the population of flea beetles compared to other leaf extracts; Chromolaena odorata and Ageratum conyzoides at $24.6 \%$ and $23.3 \%$ correspondingly. This shows that leaf extracts of Carica papaya significantly $(\mathrm{P}<0.05)$ reduced the population of flea beetles than other leaf extracts. The synthetic insecticide (Deltamethrine) was observed to be most active and significantly $(\mathrm{P}<0.05)$ effective in reducing the population of flea beetles when compared to plant extracts.

\begin{tabular}{|l|c|c|}
\hline \multicolumn{1}{|c|}{ Treatment } & $\begin{array}{c}\text { Insect Population } \\
\text { (\%) Before Treat- } \\
\text { ment Application }\end{array}$ & $\begin{array}{c}\text { Insect Population } \\
\text { (\%)After Treatment } \\
\text { Application }\end{array}$ \\
\hline $\begin{array}{l}\text { Chromolaena } \\
\text { odorata }\end{array}$ & 18.9 & 24.6 \\
\hline Carica papaya & 21.2 & 20.7 \\
\hline $\begin{array}{l}\text { Ageratum } \\
\text { conyzoides }\end{array}$ & 21.9 & 23.3 \\
\hline Deltamethrine & 20.4 & 6.5 \\
\hline Control & 17.6 & 24.9 \\
\hline LSD $(0.05)$ & 0.26 & 0.32 \\
\hline
\end{tabular}

Table 1: Effects of plant extracts and synthetic insecticide on the population of flea beetles (Podagrica SPP.).

Effects of plant extracts and synthetic insecticide on the percentage defoliation of okra leaves

The results of the defoliation percentage of okra leaves before and after application of treatments are represented in table 2 . Okra plants treated with leaf extracts of Carica papaya recorded the lowest leaf defoliation while the highest the defoliation was recorded on the plants in the control plots. The effect of the leaf extracts of Carica papaya led to defoliation percentage of $57.7 \%$ compared to leaf extracts of Chromolaena odorata and Ageratum conyzoides at $61.8 \%$ and $70 \%$ respectively. However, the plant extracts were not as effective as the synthetic insecticide (Deltamethrine) in lowering leaf defoliation per plant.

Effects of plant extracts and synthetic insecticide on the okra fruit yield and okra plant height

The results of the plant height before and after application of treatments and yield of okra are presented in table 3. Okra plants treated with leaf extracts of Carica papaya recorded the highest plant height. The effect of leaf extract Carica papaya led to plant

\begin{tabular}{|l|c|c|}
\hline \multicolumn{1}{|c|}{ Treatment } & $\begin{array}{c}\text { Defoliation (\%) } \\
\text { Before Treatment } \\
\text { Application }\end{array}$ & $\begin{array}{c}\text { Defoliation (\%) } \\
\text { After Treatment } \\
\text { Application }\end{array}$ \\
\hline $\begin{array}{l}\text { Chromolaena } \\
\text { odorata }\end{array}$ & 96.3 & 61.8 \\
\hline Carica papaya & 94.9 & 57.7 \\
\hline $\begin{array}{l}\text { Ageratum } \\
\text { conyzoides }\end{array}$ & 95.2 & 70 \\
\hline Deltamethrine & 97.7 & 20.7 \\
\hline Control & 90.3 & 70.5 \\
\hline LSD $(0.05)$ & 0.1942 & 0.3365 \\
\hline
\end{tabular}

Table 2: Effects of plant extracts and synthetic insecticide on the percentage defoliation of okra leaves.

height of $29.60 \mathrm{~cm}$ compared to leaf extracts of Chromolaena odorata and Ageratum conyzoides at $29.40 \mathrm{~cm}$ and $23.83 \mathrm{~cm}$ respectively.

\begin{tabular}{|l|l|l|l|}
\hline Treatment & $\begin{array}{c}\text { Plant Height Be- } \\
\text { fore Treatment } \\
\text { Application(Cm) }\end{array}$ & $\begin{array}{c}\text { Plant Height } \\
\text { After Treatment } \\
\text { Application(Cm) }\end{array}$ & $\begin{array}{c}\text { Fresh Fruit } \\
\text { Yield } \\
\text { (Kg/Ha) }\end{array}$ \\
\hline $\begin{array}{l}\text { Chromolaena } \\
\text { odorata }\end{array}$ & 10.55 & 29.40 & 633 \\
\hline $\begin{array}{l}\text { Carica pa- } \\
\text { paya }\end{array}$ & 13.67 & 29.60 & 1748 \\
\hline $\begin{array}{l}\text { Ageratum } \\
\text { conyzoides }\end{array}$ & 15.17 & 23.83 & 1124 \\
\hline Deltamethrin & 13.28 & 22.40 & 2366 \\
\hline Control & 11.13 & 22.60 & 578 \\
\hline LSD (0.05) & 1.545 & 4.273 & 1438.4 \\
\hline
\end{tabular}

Table 3: Effects of plant extracts and synthetic insecticide on the okra fresh fruit yield and okra plant height.

It was observed that plants treated with leaf extracts of Carica papaya had higher yield of $1.40 \mathrm{~kg} / \mathrm{ha}$ than those sprayed with leaf extracts of Chromolaena odorata, and Ageratum conyzoides at $0.49 \mathrm{~kg} / \mathrm{ha}$ and $0.84 \mathrm{~kg} / \mathrm{ha}$ respectively. Okra plants treated with distilled water (control) had lowest yield $(0.43 \mathrm{~kg} / \mathrm{ha}$ ) when compared to other treatments. On the other hand, plots treated with synthetic insecticide (Deltamethrine) had the highest yield compared to the plant extracts.

\section{Discussion}

The lowest defoliation and reduction of insect population which was recorded on okra plants treated with leaf extracts of Carica papaya showed that it had a better control against field insect pest of okra (Podagrica spp.) and proved significantly different from distilled water (control). These agree with the findings of James. et al. [13] who conducted field trials to assess the efficacy of leaf extracts of neem (Azadirachta indica), pawpaw (Carica papaya), and bulb extract of onion (Allium cepa) and untreated (control) for the control of two species of flea beetles (Podagrica uniforma and Podagrica sjostedti). Plant extracts have been shown to have insecticidal properties [14]. This also agree with the work by Echero- 
bia., et al. (2010), who reported that $10 \%$ aqueous extracts of Piper guineense and Azadirachta indica could be used as repellents in the control of okra flea beetles. Emeasor and Okorie [15], had also reported the control of maize weevil (Sitophilus zeamais) in the stored maize grain by Citrus sinensis rind oil.

Among the plant extracts, leaf extract of Carica papaya proved to be most effective in reduction of the population of flea beetles. These result confirmed the previous work carried out by Coelho., et al. (2009), Freitas., et al. (2010), and Ravikumar., et al. (2011) who reported that the plant extracts exhibit insecticidal properties through ovipositional deterrence, larvicidal effects, repellency, and as insect growth regulator. Plants in the control plots were found to have more defoliation and high insect population, while in the other cases where okra plants were treated with plant extracts, reduction both in defoliation and insect population was observed. It is thus obvious that extracts of plants were able to control insect population (Podagrica spp.) of okra especially the leaf extract of Carica papaya.

The yield difference between okra plants treated with leaf extracts of Carica papaya, Chromolaena odorata, Ageratum conyzoides, distilled water (control) and synthetic insecticide (Deltamethrine) indicated that Podagrica spp. infestation can reduce the yield of okra. Okra yield can be significantly reduced also by the yellow vein mosaic virus, powdery mildew (Erysiphe cichoracearum), fruit borer (Earias vittela) and jassids (Amarasca biguttala) [16]. Yield reduction can also be affected by other parameters such as poor soil nutrient, flooding and other environmental factors (Olasantan, 2004; Akinyele., et al. 2007). Mochiah., et al. 2011, also observed that vegetables in which botanicals were applied produced the highest mean fruit weight and fruit numbers (yield) of okra and eggplant, supporting what was discovered in this work as the fruit weight and numbers (yield) of okra treated with the botanicals were found to be significantly higher than the fruit weight and number (yield) of the untreated plot. This could be as a result of high level of population of flea beetles in the untreated plots that defoliated larger proportion of the leaf surface thereby inhibiting cell multiplication, amino acid synthesis and energy formation which invariably inhibit photosynthetic ability of the plant, its products thereby not easily translocated to the sinks (Eifedeyi and Remison, 2010) [17-44].

\section{Conclusion and Recommendation}

The plant extract of Carica papaya could successfully serve as the best option in the pest management considering its effectiveness in reducing the population of flea beetles which translated to better yield. This botanical is effective, eco-friendly, cheap, readily available and do not pose any threat to the user. It is due to these reasons that aqueous extract from leaf of Carica papaya which showed insecticidal activities in controlling field insect pest of okra is recommended. There is need to investigate further on effectiveness of combined application of these botanicals on pests that attack crops to reduce total reliance on synthetic pesticides. Based on the result of this work, however further research work on the use of other extractors or solvents should be investigated.

\section{Bibliography}

1. Lamont W. "Okra a versatile vegetable crop". Hort. Technology 9 (1999): 179-184.

2. Arapitsas P. "Identification and qualification of polyphenolic compounds from okra seedsand skins". Food chemistry 110 (2008): 1041-1045.

3. Babatunde RO., et al. "Socio- Economic Characteristics and Food Security Status of Farming Household in Kwara State, North-Central Nigeria". Pakistan Journal of Nutrition 6 (2007): 16.

4. Kemble JM., et al. "Guide to commercial okra production (1995).

5. Iremiren GO and Okiyi DA. "Effects of sowing dates on the growth, yield and quality of okra in southern Nigeria". Journal of Agricultural Science 106 (1986): 21-26.

6. IFA. World Fertilizer Use Manual. Publication of International Fertilizer Industry (1992).

7. Markose BL and Peter KV. "Okra. Review of research on vegetable and Tuber crops". Technical Bulletin 16. Kerala Agricultural University Press Mannuthy, Kerala (1990): 109.

8. Egwuatu RI. "Field trials with systemic and contact insecticide for the control of Podagrica uniforma and P. sjostedtii (Coleoptera: Chrysomelidae) on okra". Tropical Pest Management 28.2 (1982): 115-121.

9. Lana AO and Tarlor AT. "The insect transmission of an isolate of okra mosaic virus occurring in Nigeria". Annuals of Applied Biology 82 (1976): 361-364.

10. Asawalam EF and Dioka UJ. "Evaluation of toxicity of Dennitia tripetala baker (F.) and Curcuma longa (I.) rhizome against cowpea seed bruchid, Callosobruchus maculates (F.) Coleoptera: Bruchidae". Agricultural Science Research Journal 2 (2012): 308-311.

11. Asawalam EF and Adesiyan SO. "Potentials of Ocimum basilicum (Linn) for control of maize weevil, Sitophilus zeamais (Motsch)". Nigeria Agricultural Journal 32 (2001): 195-201.

12. Jewel KB. "How to grow crops without Endosulfan". Field Guide to Non-Chemical Pest Management (2008): 52.

13. James Adebayo Ojo., et al. "Evaluation of Botanical Insecticides Against Flea Beetles Podagrica sjostedtii and Podagrica uniforma of okra". International Journal of Advanced Research 2 (2014): 236-244.

14. Kamsuk K., et al. "Effectiveness of Zanthoxylum piperitumderived essential oil as an alternative repellent under laboratory and field services". Parasitology Research 100 (2007): 339-345. 
15. Emeasor KC and Okorie CC. "Comparative efficacy of sweet orange, Citrus sinensis (L.) rind powder and oil for the control of maize weevil, Sitophilus zeamais (Motchulsky)". Journal of Tropical Agriculuture Food, Environment and Extension 7 (2008): 9-114.

16. Ali M., et al. Euphytica 111 (2000): 205-209.

17. Olasantan FO and Bello NJ. Journal of Agricultural Science, Cambridge, 142 (2004): 49-58.

18. Adenuga AO. "Field insecticidal trials for the control of insect pest of okra, Abelmoschus esculentus". African Journal of Agricultural Research 4.12 (1997): 1488-1492.

19. Ahmed BI., et al. "Comparative efficacy of different concentrations of some promising insecticides for the control of Podagrica spp. (Coloeptera: Chrysomelidae) on okra (Abelmoschus esculentus (L.) moench)". Global Journal of Agricultural Science 6 (2007): 31-34.

20. Akinyele BO and Temikotan T. "Effectiveness of variation soil texture on the vegetative and characteristics of okra (Abelmoschus esculentus (L.) moench)". International Agricultural Resources 2 (2007): 165-169.

21. Anaso CE and Lale NES. "Efficacy of neem oil on Podagrica spp., Sylepta derogate (f) and Helicoverpa armigera (Hb) on okra in Sudan savanna of Nigeria". Journal of Arid Agriculture 11 (2001a): 55-63.

22. Anaso CE and Lale NES. "Evaluation of aqueous neem kernel extract for the control of major insect pests of okra (Abelmoschus esculentus (L) Moench.) in Nigeria Sudan savanna". Journal of Arid Agriculture 11 (2001b): 65-72.

23. Attieri MA. "Designing and Improving Pest Management Systems for Subsistence Farmers (Attieri, M.A. Ed.)". West View Press Inc., Boulder and San Francisco (1993): 1-20.

24. Baidoo PK and Adam JI. "The Effects of Extracts of Lantana camara (L.) and Azadirachta indica (A. Juss) on the Population Dynamics of Plutella xylostella, Brevicoryne brassicae and Hellula undalis on Cabbage". Sustainable Agriculture Research 1 (2012).

25. Brunt A., et al. Plant Viruses Online: Description and Lists from the VIDE Database (1997).

26. Chinniah C and Ali KA. "Relative efficacy of insecticides/acarides against sucking insects of okra". Pest Management and Economic Zoology 8 (2000): 111-116

27. ECHO. Plant information sheet, N.FT. Meyers, USA (2003).

28. Eifediyi EK and Remison SU. "The effects of inorganic fertilizer on the yield of two varieties of Cucumber (Cucumis sativus (L.)". Report and Opinion 2.11 (2010): 1-5.
29. Emeasor KC., et al. “Insecticidal activity of some seed powders against Callosobruchus maculates (F.) (Coleoptera: Bruchidae) on stored cowpea". Journal of Plant Diseases and Protection 112 (2005): 80-87.

30. Emosairue SO and Ukaegbu GC. "Effect of Lambda-cyhalothrin on the Population of Podagrica uniforma (jacoby) and P. sjostedtii (Jacoby) and the yield of okra (Abelmoschus esculentus (L.) Moench.) in the Calabar humid area". Journal of Applied Chemical Agriculture Research 1 (1994): 25-29.

31. Emosairue SO and Uguru EI. "Field trial of aqueous and petroleum ether extracts of Monodora myristica (gaertn). Dunal and Jatropha curcas (L.) for the control of okra flea beetles, Podagrica spp". Journal of Applied Chemical Agriculture and Research 6 (1999): 100-104.

32. Fasuwon BT and Banjo AD. Research Journal of Agriculture and Biological Sciences 6 (2010): 283-288.

33. Gerken A., et al. "Crop production policy in Ghana. Pesticide policy Project Produced by Plant Protection and Regulatory Services". Directorate of Ministry of Food and Agriculture, Accra (2000).

34. Hassan S., et al. "Pesticide utilization in Mubi area and associated hazards: A Survey". Journals of Sustainable Development of Agriculture and Environment 3 (2007): 89-95.

35. Isman MB. "Botanical insecticides, deterrents, and repellents in modern agriculture and an increasily regulated world". Annual Review of Entomolgy 51 (2006): 45-46.

36. Isman MB., et al. "Insecticidal and antifeedant bioactives of neem oil and their relationship to azadirachtin content". Journal Agricultural Food Chemical 38 (1990): 1406-1411.

37. Inyand UE. "Laboratory assessment of the repellent and antifeedant properties of aqueous extracts of 13 plants against the banana weevil Cosmopolites sordidus Germar (Coleoptera: Curculionidae)". Tropical and Subtropical Agroecosystems 5 (2005): 33-44.

38. Kamble JM., et al. "Guide to commercial okra production" (1985).

39. Lambert J., et al. "Bruchid Control with traditionally used insecticidal plant" (1985).

40. Olaniran OA. "Control of foliage pests of roselle (Hibiscus sabdariffa (L.) using plant extracts of Tephrosia vogetii and Azadirachta indica in Ogbomoso, Nigeria". Transnational Journal of Science and Technology 3 (2013).

41. Obeng-Ofori D and Ankrah DA. "Effectiveness of aqueous neem extracts for the control of insect pests of cabbage (Brassica oleracea var capitates L.) in the Accra plains of Ghana". Agricultural Food Science Ghana, 1 (2002): 83-94. 
42. Obeng- Ofori D and Sackey J. "Field evaluation of non-synthetic insecticides for the management of insect pests of okra (Abelmoschus esculentus (L.) Moench) in Ghana". Ethiopian Journal of Agricultural Science 26 (2003): 145-150.

43. Odebiyi JA., et al. "Assessment of damage caused by the leaf eating beetles, Podagrica spp. On okra in southeastern Nigeria”. African Journal of Agricultural Science 8 (1981): 103-112.

44. Oladimeji A and Kannike MA. "Comparative studies on the efficacy of neem, basil leaf extracts and synthetic insecticide, Lambda-cyhalothrin, against Podagrica spp. On okra". African Journal of Microbiology Research 4 (2010): 033-037.

\section{Volume 3 Issue 11 November 2019}

(C) All rights are reserved by Afshan., et al. 